Univerzitet u Beogradu
Poljoprivredni fakultet
Institut za poljoprivrednu tehniku
Naučni časopis
POLJOPRIVREDNA TEHNIKA
Godina XLVI
Broj 2, 2021.
Strane: $11-18$
Faculty of Agriculture

\title{
A STUDY OF AERODYNAMIC PROPERTIES OF YAM FLOUR
}

\author{
Chineze Glory Okeke ${ }^{* 1}$ and Sylvester Ike Oluka ${ }^{1}$ \\ Department of Agricultural and Bioresource Engineering, Faculty of Engineering, \\ Enugu State University of Science and Technology, Enugu, Nigeria.
}

\begin{abstract}
The aerodynamic properties of five varieties of Yam namely: white yam, purple yam, three leaves yam, water yam and yellow yam were investigated under oven drying methods at $33^{\circ} \mathrm{C}$. The dried yams were milled to flour and were taken to laboratory to determine their aerodynamic properties with respect to pneumatic conveying of the yam flours. The yam flour varieties recorded terminal velocity range of 1.38 to $1.60 \mathrm{~m} / \mathrm{s}$. Drag coefficient of 0.47 and Reynolds number varying from 0.63 to $0.97 \times 10^{-5} \mathrm{kgm}^{-2} / \mathrm{s}$. The analysis of variance conducted on the effect of yam varieties on the aerodynamic properties of yam flour did not show significant difference at both $5 \%$ and $1 \%$ level of probability. The study will guide engineers in design of yam flour pneumatic conveying equipment.
\end{abstract}

\section{Key words: Aerodynamic properties, pneumatic conveying, Yam flour, drag coefficient.}

\section{INTRODUCTION}

Aerodynamics is a branch of dynamics that deals with the movement of air and other gaseous fluids as it relates to forces acting on bodies moving through such fluids. It is the study of movement of air and the interaction between the air and solids passing through the air [1] In the course of this research work, focus will be on pneumatic conveying.

\footnotetext{
${ }^{*}$ Corresponding Author. E-mail address: chinezeglory @ yahoo.com
} 
Pneumatic conveying is the movement of flour/powder and other granules using air as a medium.

It is a method of moving material using air as a transporting medium. Pneumatic conveying can be achieved through negative conditions (vacuum) or positive conditions (pressure) [2].

The bulk granules or material are conveyed through an enclosed system (pipeline) by collective force of pressure and air flow used to convey the materials. It has many advantages over mechanical conveyors as follows, (1) Closed system conveying reduces cross contamination (2) Ease of automation, control and routing flexibility. (3) Easy dust control (4) Cost savings in flight rate of bulk materials (5) Lower maintenance, power and labour [3].

Aerodynamic properties are essential parameters in hydraulic conveyance and handling as well as hydraulic categorization of agricultural products.

To generate simple data for the development of machines for sorting, conveying and sizing of agricultural products, some properties like physical characteristics and terminal velocity are required. The two most important aerodynamic properties of a body are its terminal velocity and drag force (drag coefficient too). Relating the terminal velocity of different threshed materials, it is likely to determine and set the highest possible air velocity in which grain materials can be separated without loss of grain or the principle can be adopted to sort grain into different size groups.

More so, agricultural materials and food products are usually conveyed using air. The interaction force between the solid particles and the moving fluids determine the forces applied to the particles. This interaction is influenced by the density, shape, and size of the particle along with the viscosity, density and velocity of the fluid [4].

Terminal velocity and drag coefficient of agricultural materials are important in designing of air/hydro conveying equipment and separation systems. Air is frequently used as a conveyer for conveying or for separating the sough table materials; therefore terminal velocity and drag coefficient are required for air conveying and pneumatic separation of products [5]. In processing of biomaterials, air is usually used as a mover for transport or for sorting out the desirable products from unwanted materials, hence the aerodynamic properties such as terminal velocity and drag coefficient are required for air conveying and pneumatic sorting of biomaterials. When the air velocity is higher than terminal velocity, it lifts the particles; and to allow greater fall of a particle, the air velocity could be adjusted to a level just below the terminal velocity. Terminal velocity is the highest velocity an object can reach as it falls through a fluid (example is air). It arises when the addition of the drag force $\left(\mathrm{F}_{\mathrm{d}}\right)$ and the buoyancy is equal to the downward force of gravity acting on the object. Subsequently, if the net force on the object is zero, the object has no acceleration. An object is said to move at its terminal velocity in fluid dynamics if its speed is continuous as a result of the restrictive force exerted by the fluid through which it is moving [6]. When the speed of an object increases, the drag force acting on it increases, and it all depends on the substance through which it passes (example is air or water). At some speed, the drag or force of resistance may equal the gravitational pull on the object (buoyancy is considered below). At this point the object stops to accelerate and continues falling at a constant speed called the terminal velocity (it is also known as settling velocity). 
An object moving downward faster than the terminal velocity will slow down till it gets to the terminal velocity.

Drag is dependent on the projected area, the object's cross-section in a horizontal plane. An object with a big projected area relative to its mass, such as a parachute, has a lower terminal velocity than one with smaller projected area [7]

Pneumatic conveying is an innovative technology that facilitates the transference of solids in an enclosed system. It enables the solids to be homogenized into a stream of gas and uses pressure and/or vacuum to move the gas stream with the entrained solids [8] The solids to gas relationship, and resultant flow rates and pressures are controlled and observed for efficient conveying of the solids from their primary source to a secondary place. The solids are alienated from the gas stream by a dust collection or filter element, which is classically a major component of this type of equipment. Pneumatic conveying is an innovative, simple solution to numerous outdated conveying difficulties.

It is a reliable substitute to mechanical conveyors that operate with moving parts such as belts, screws, rollers, vibrating plates, elevator buckets, drag chain, cables, discs, etc. [9]. These systems can work efficiently for conveying large objects, although they are limited in the ability to safely and effectively convey small and fine particles such as plastic pellets, soda ash, talc, cement, silica and alumina [10].

Pneumatic conveying is extensively used in industry to handle and move dry and free-flowing powdered and granular material because it is appropriate for diverse processes. Fine particles of less than 1 micron as well as $15 \mathrm{~mm}$ solids, can be conveyed vertically and horizontally from distances of few meters to a few kilometers at rates of hundreds of tons per hour. Though pneumatic conveying involves a greater power usage and more expertise than mechanical conveying, it has less Initial capital investment; it requires less control and maintenance, takes up little space and pipeline are easier routed. It shields the material from the environs by enclosing it, and it is cleaner and easier to automate. The system is totally enclosed which means that harmful materials can be safely conveyed, and dust is reduced. The objective of this study is to investigate the aerodynamic properties of yam flour which will guide engineers in design of yam flour pneumatic conveying system and equipment.

\section{MATERIALS AND METHODS}

\section{Research Materials}

The research materials include five varieties of yam flours: White Yam (Dioscorearutundata), Purple Yam (Dioscoreaalata), Yellow Yam (Dioscoreacayenensis), Three leaves yam (Dioscoreabulbifera) and Water yam (Dioscoreaalatalinn).

\section{Research apparatus}

The following apparatuses/equipment was used for the experiment: 
1. Drying equipment: An electric oven dryer of model LOA 1805, Munich Germany; A Solar dryer (solar energy collector) locally fabricated; it was made of metallic box having gross dimensions. The gross dimensions of the absorber plate are $1.0 \mathrm{~m}$ long, $0.62 \mathrm{~m}$ wide and $0.55 \mathrm{~mm}$ thickness with a net surface area of $0.62 \mathrm{~m}^{2}$.

2. Analytical balance (Model PA 2120; sensitivity 0.001g Ohaus Co, Pine Brook NJ, USA) used for samples weight measurement.

Sample preparation

\section{Experimental Procedure}

The yam tubers were washed, hand-peeled and sliced to range of 10 to $15 \mathrm{~mm}$ thickness. The sliced yam tubers were generally dried to a constant weight and milled accordingly using Laboratory hammer mill. The yam flour was separately kept in moisture resistant/air tight container and was taken to the laboratory for aerodynamic properties tests.

\section{Determination of Aerodynamic Properties of Yam Flour}

Measurement of terminal velocity

The terminal velocity of the Yam flour was determined using equation (1) according to [11].

$$
\mathrm{Vt}=\sqrt{\frac{2 m g}{\rho A C d}}
$$

Where:

$\mathrm{V}_{\mathrm{t}}=$ terminal velocity/s

$\mathrm{m}=$ mass of the falling object, $\mathrm{g}$

$\mathrm{g}=$ acceleration due to gravity, $\mathrm{m} / \mathrm{s}$

$\mathrm{Cd}=$ drag coefficient

$\rho=$ density of the fluid through which the object is falling, $\mathrm{g} / \mathrm{cm}^{3}$

$\mathrm{A}=$ projected area of the object, $\mathrm{cm}^{2}$

Evaluation of Reynolds number

The Reynolds numbers of the yam flours were evaluated from the measured terminal velocity and diameter of the samples using the expression as propounded by [12] and adopted by [13].

$$
\mathrm{N}_{\mathrm{R}}=\frac{V t D}{N f}
$$

here:

$\mathrm{N}_{\mathrm{R}}=$ Reynolds Number (dimensionless)

$\mathrm{V}_{\mathrm{t}}=$ terminal velocity, $\mathrm{m} / \mathrm{s}$

$\mathrm{f}=$ air density $\mathrm{g} / \mathrm{cm}^{3}$

$\mathrm{D}=$ diameter of flours $(\mathrm{m})$

$\mathrm{N}=$ air/kinematic viscosity, $\mathrm{kgm}^{-2} / \mathrm{s}$ 
The air density is assumed to be $1.15 \mathrm{~kg}^{-1}$ and kinematic viscosity $1.88 \times 10^{6} \mathrm{kgm}^{-2} \mathrm{~s}$ at constant laboratory temperature and pressure.

Estimation of the effective diameter of the flour

The diameter of the yam flour was measured using the method adopted by [14] as described by [15] in which $20 \mathrm{~g}$ of flour was poured inside a funnel of orifice diameter of $0.8 \mathrm{~cm}$, clamped at height of $10 \mathrm{~cm}$; and the flour samples were allowed to flow freely to a flat platform to an arbitrary height and the diameter (D) of the heap of the flour was measured and recorded.

Determination of drag coefficient

The shape of the yam flour was spherical and the calculated drag coefficient for spherical biomaterials is $0.47[11]$

\section{RESULTS AND DISCUSSION}

Table 1. Aerodynamic Characteristic of Yam Flour Varieties

\begin{tabular}{|c|c|c|c|c|}
\hline $\begin{array}{l}\text { Yam } \\
\text { Value }\end{array}$ & Property & Mean \pm SD & $\begin{array}{l}\text { Maximum } \\
\text { Value }\end{array}$ & $\begin{array}{l}\text { Minimum } \\
\text { Value }\end{array}$ \\
\hline \multirow[t]{3}{*}{ White Yam } & $\begin{array}{c}\text { Terminal Velocity } \\
\mathrm{m} / \mathrm{s}\end{array}$ & $1.37 \pm 0.12$ & 1.52 & 1.22 \\
\hline & $\begin{array}{l}\text { Reynolds Number } \\
\left(\mathrm{N}_{12} \times 10^{-5}\right)\end{array}$ & $0.68 \pm 1.41$ & 1.02 & 0.34 \\
\hline & Drag Coefficient & 0.47 & 0.47 & 4.7 \\
\hline \multirow[t]{3}{*}{ Three Leaves Yam } & $\begin{array}{l}\text { Terminal Velocity } \\
\mathrm{m} / \mathrm{s}\end{array}$ & $0.97 \pm 0.03$ & 1.60 & 1.31 \\
\hline & $\begin{array}{c}\text { Reynolds Number } \\
\left(\mathrm{N}_{12} \times 10^{-5}\right)\end{array}$ & $0.93 \pm 1.32$ & 1.06 & 0.44 \\
\hline & Drag Coefficient & 0.47 & 0.47 & 4.7 \\
\hline \multirow[t]{3}{*}{ Purple Yam } & $\begin{array}{c}\text { Terminal Velocity } \\
\mathrm{m} / \mathrm{s}\end{array}$ & $1.38 \pm 2.11$ & 1.49 & 1.26 \\
\hline & $\begin{array}{c}\text { Reynolds Number } \\
\left(\mathrm{N}_{12} \times 10^{-5}\right)\end{array}$ & $0.68 \pm 0.24$ & 1.04 & 0.31 \\
\hline & Drag Coefficient & 0.47 & 0.47 & 4.7 \\
\hline \multirow[t]{3}{*}{ White Yam } & $\begin{array}{c}\text { Terminal Velocity } \\
\mathrm{m} / \mathrm{s}\end{array}$ & $1.28 \pm 5.13$ & 1.38 & 1.18 \\
\hline & $\begin{array}{c}\text { Reynolds Number } \\
\left(\mathrm{N}_{12} \times 10^{-5}\right)\end{array}$ & $0.63 \pm 1.23$ & 1.01 & 0.24 \\
\hline & Drag Coefficient & 0.47 & 0.47 & 4.7 \\
\hline \multirow[t]{3}{*}{ Yellow Yam } & $\begin{array}{c}\text { Terminal Velocity } \\
\mathrm{m} / \mathrm{s}\end{array}$ & $0.97 \pm 0.03$ & 1.60 & 1.31 \\
\hline & $\begin{array}{l}\text { Reynolds Number } \\
\left(\mathrm{N}_{12} \times 10^{-5}\right)\end{array}$ & $0.93 \pm 1.32$ & 1.06 & 0.44 \\
\hline & Drag Coefficient & 0.47 & 0.47 & 4.7 \\
\hline
\end{tabular}


Table 2. Effect of yam type on the Aerodynamic properties of yam flour

\begin{tabular}{|c|c|c|c|c|c|c|}
\hline $\begin{array}{c}\text { Source } \\
\text { of variation }\end{array}$ & D.F. & $\begin{array}{c}\text { Sum of } \\
\text { Squares (SS) }\end{array}$ & $\begin{array}{c}\text { Mean square } \\
\text { (MD) }\end{array}$ & \multicolumn{2}{|c|}{ F.Cal } & \multicolumn{2}{|c|}{ F.Tab } \\
\hline CFM & 1 & 64.21156 & & & $5 \%$ & $1 \%$ \\
\hline Yam varieties & 4 & 2.28484 & 0.57121 & $0.073^{\mathrm{NS}}$ & 5.19 & 11.39 \\
\hline Error & 5 & -39.055 & 7.811 & & & \\
\hline Total & 9 & -39.72066 & & & & \\
\hline
\end{tabular}

Table 1., presents the aerodynamic behaviors of the yam flour varieties. Results revealed that three leaves yam had the highest range of terminal velocity of 1.31 to $1.60 \mathrm{~m} / \mathrm{s}$, followed by white yam with terminal velocity range of 1.22 to $1.52 \mathrm{~m} / \mathrm{s}$, yellow yam $(1.24-1.50 \mathrm{~m} / \mathrm{s})$, purple yam $(1.26-1.49 \mathrm{~m} / \mathrm{s})$ and least was water yam with terminal velocity range of $1.18-1.38 \mathrm{~m} / \mathrm{s}$.

The terminal velocity of the yam flours are within the range of terminal velocity obtained by [13] which indicated that pneumatic conveying of the flour is possible with minimum or no loss of the flour.

Furthermore, yellow yam recorded the highest Reynolds number varying from 0.39 x $10^{-5}$ to $1.09 \times 10^{-5}$ with mean value of $0.74 \times 10^{-5} \mathrm{kgm}^{-2} / \mathrm{s}$, and standard deviation of 0.08 followed by three leaves yam with Reynolds number of $0.44 \times 10^{-5}$ and standard deviation of 1.32 . The least Reynolds number was recorded by white yam $\left(0.34 \times 10^{-5}\right.$ to $1.02 \times 10^{-5} \mathrm{kgm}^{-2} / \mathrm{s}$, with mean and standard deviation of $0.68 \pm 141$.

The yam varieties generally had uniform drag coefficients of 0.47 according to the assumption of [11].

Finally, The analysis of variance ANOVA conducted on the effect of yam varieties on the aerodynamic properties of yam flour (Table 2) did not show significant difference at both $5 \%$ and $1 \%$ level of probability.

\section{CONCLUSIONS}

1. Based on the findings from the research work, the following conclusions can be made: The yam flour varieties had terminal velocity range of 0.98 to $1.60 \mathrm{~m} / \mathrm{s}$ with Drag coefficient of 0.47 .

Reynolds number varying from 0.63 to $0.97 \times 10^{-5} \mathrm{kgm}^{-2} / \mathrm{s}$ hitch is indeed an indication that pneumatic conveyance of the flours are possible.

2. Yam type has no significant effect on the aerodynamic properties of the yam flours

3. The result showed that less energy cost is required in designing a pneumatic conveying system for the studied yam floors.

\section{REFERENCES}

[1] Kun.X .2019. Advances in aerodynamics (AIA). https://aia.springeropen.com

[2] Dekker. M. 2004. A handbook of pneumatic conveying engineering. Marcel Dekker, Inc.

[3] Powder bulk solids . 2014.www. jetsolutions.ch 
[4] Ying S, Beiham .J and Heidi M. N.2016. Influence of particular size and density and channel velocity on the deposition patterns around a circular patch of model emergent vegetation. Journal of Advancing earth and space science. Vol.52., pp. $1044-1055$.

[5] Metin G. 2007. Pneumatic Conveying Characteristics of some Agricultural seeds. Journal of Food Engineering.80(3) $904-913$.

[6] Robert A. B.1991. Fluid Mechanics of the Atmosphere. Int. Geophysics Vol.47., pp.7 - 83.

[7] NASA Glenn Research Center "Terminal Velocity".Retrieved March 4, 2018.

[8] Haoyu W., Ahmad M., Anh.Phan., Vladimir Zivkovic., David Reay., Richard Law., Kamelia Boodhoo. 2017. A review of process intensification applied to solids handling. Chemical Engineering and Processing.Vol. 118, August 2017., pp. 78-107.

[9] Processing magazine . 2018. https://www.processingmagazine.com(accessed dec.2018).

[10] Oke, M. O, Awonori, S. O. and Workneh, T.S. 2013. Effect of varieties on physicochemical and pasting characteristics of water yam flours and starches. African Journal of Biotechnology12 (11):1250-1256.

[11] Briens C.L.1991. Correlation for direct calculation of the terminal velocity of spherrical particles in Newtonian and pseodoplastic materials. ELSEV..Vol. 67. Issue 1., pp 87 - 91.

[12] Mohsenin, N.N. 1970. Physical Properties of Plant and Animal Materials, 2nd Ed. Gordon and Breach Science Publishers, New York.

[13] Oduma, O., Igboke, M. E and Ali, F.U. 2014. Physical and aerodynamic characterization of pigeon pea kernel, Hull and stalk materials, JASBER. Vol . 3(1 \& 2). pp. 1 - 13.

[14] Olorunsola, E, O., Adamu, B. I. and ZamanY. E. 2012. Physicochemical properties of borassusaethiopumstarch. Asian J. Pharm. Clin. Res. 5(Suppl. 3):132-134.

[15] Nwosu J. N. 2010. Effect of soaking, Blanching and cooking on the anti-nutritional properties of Asaparagas beans flour. Nature and science J. 8 (a): pp.163 -167.

\section{ISTRAŽIVANJE AERODINAMIČKIH OSOBINA YAM BRAŠNA}

\section{Chineze Glory Okeke ${ }^{1}$ and Sylvester Ike Oluka ${ }^{1}$}

${ }^{1}$ Department of Agricultural and Bioresource Engineering, Faculty of Engineering, Enugu State University of Science and Technology, Enugu, Nigeria

Sažetak. Aerodinamičke osobine pet sorti Yam zrna za: Beli (Dioscorearutundata), Ljubičasti (Dioscoreaalata), Žuti (Dioscoreacayenensis), Trolisni (Dioscoreabulbifera), i Vodeni (Dioscoreaalatalinn), istražene su sušenjem u peći na $33^{\circ} \mathrm{C}$.

Osušena zrna Yam su samlevena u brašno, da bi se odredile njihove aerodinamičke osobine, zbog kasnije mogućnosti pneumatskog transporta brašna.

Ispitane sorte Yam brašna imaju krajnju brzinu od 1,38 do 1,60 m/s. Koeficijent otpora je 0,47 i Reynolds broj varira od 0,63 do $0,97 \times 10^{-5} \mathrm{kgm}^{-2} / \mathrm{s}$.

Analiza varijanse sprovedena na efektu uticaja Yam varijeteta na aerodinamičke osobine brašna nije pokazala značajnu razliku na nivou verovatnoće od 5\% i 1\%.

Studija bolje upućuje inžinjere u dizajniranje opreme za pneumatski transport Yam brašna. 
Ključne reči: Aerodinamičke osobine, pneumatski transport, Yam brašno, koeficijent otpora.

Prijavljen:

Submitted:

22.02.2021.

Ispravljen:

Revised:

10.04.2021.

Prihvaćen:

Accepted:

10.05.2021. 